\title{
CONTRIBUTION OF SERVICES TO ECONOMIC GROWTH: KALDOR'S FIFTH LAW?
}

\author{
ADILSON GIOVANINI* \\ Universidade Federal de Santa Catarina (UFSC), Santa Catarina - SC, Brazil. \\ MARCELO AREND** \\ Universidade Federal de Santa Catarina (UFSC), Santa Catarina - SC, Brazil.
}

To cite this article: Giovanini, A., \&; Arend, M. (2017). Contribution of services to economic growth: Kaldor's fifth law? Revista de Administração Mackenzie, 18(4), 190-213. doi 10.1590/167869712017/administracao.v18n4p190-213

* Bolsista de doutorado Fapesc.

** Bolsista de estágio pós-doutoral Capes. 


\section{ABSTRACT}

Purpose: This study questions whether there is a Kaldor's fifth law and tests whether the size of the intermediate services sector contributes to the growth of the industrial sector.

Originality/Value: The laws proposed by Kaldor consider that the industrial sector contributes to economic growth and affirm that the growth of this sector depends on the existing demand for industrial products. If this new law is corroborated we have the initial evidences that the growth of the service sector contributes to the growth of the industry. Design/methodological/approach: The existence of this new law is tested through the estimation of panel VAR models for eight developed countries in the period 1980-2009.

Findings: The growth of the service sector causes Granger to increase industrial productivity, industrial density and economic complexity. The causality test shows that there is a bidirectional causal relationship between the growth of the service sector and the industrial density and between the growth of the service sector and the Economic Complexity Index.

\section{KEYWORDS}

Kaldor. Services. Complexity. Economic Growth. Productivity.

\section{INTRODUÇÃO}

According to Kaldor (1996), the industry of transformation, which will be referred to in this paper only as the industry, plays a central role in economic growth, being the most dynamic industry and the one responsible for the differences observed between economic growth rates. These laws 
assume that industrial production growth contributes to its sector's productivity growth, prompting in its turn an economic growth process that reinforces itself.

The laws proposed by Kaldor consider that economic policies aimed at the industry are capable of promoting economic growth. This sector is the major responsible for generating an endogenous and self-sustained growth. Kaldor understands that the service sector doesn't show productivity gains and is not capable of generating persistent economic growth (Kaldor, 1966).

The literature supporting the existence of an interdependent relationship between the intermediate service sector and the industry has been growing recently. The evidence found in that literature shows that the industrial growth relays on the intermediate service sector growth, the expansion of the latter being the main factor enabling the emergence of new ideas and increase in the industry productivity (Freund \& Weinhold, 2002; Hesse \& Rodrigue, 2004; Rodrigue, 2006; Bryson et al., 2004; Miozzo \& Soete, 1999; Francois \& Woerz, 2008; Berlingieri, 2013; Cuadrado-Roura \& MarotoSanches, 2011; Jorgenson \& Timmer, 2011).

The same literature shows that the industry is constituted of different activities and, as it develops, an increasing number of more sophisticated activities emerge. These activities require more intermediate services and the emergence of these services cause countries to migrate to the manufacturing of more sophisticated industrial products. That in turn is related to higher income level (Arbache, 2015).

The new evidences put forward by the services literature allow for the consideration of various questions: Do the intermediate services contribute to the production and productivity growth in the industry? Is the growth dynamic of the industrial density, proxy to this sector's degree of technological sophistication, explained by the emergency of new service activities? Do the intermediate services contribute to an increase in production complexity of countries around the world?

In order to answer those questions, this work enquires into the existence of a fifth Kaldor's law, which shows that, as countries go through industrialization, they come to manufacture increasingly more sophisticated products that require increased amount of knowledge. Industrial sector productivity growth is in fact characterized by its diversification. Initially, it is characterized by the manufacturing of low technological intensity products and, as the intermediate services develop, it comes to manufacture more complex products. Those manufactures demand increasing volumes of knowledge. The development of an intermediate services sector specialized 
in the supply and management of that knowledge is what enables the manufacturing of these products.

This hypothesis has been tested by panel VAR models for eight developed countries (Japan, the United States, Denmark, Spain, France, the United Kingdom, Italy and the Netherlands) from 1980 until 2009. The reason for the participation of these countries is that literature shows the intermediate services sector is developed only in countries with higher income. The undertaken analytical approach considers that two of the five services sectors identified by Groningen Growth and Development Centre are intermediate services: transport; storage and communication; and financial, real estate and business services.

The estimated results corroborate the proposed hypothesis. Countries with larger services sector have also higher productivity growth rates; industrial density and economic complexity. Thus, considering the reservations related to the limits of the sample used, the results corroborate the proposed hypothesis showing initial elements favorable to the existence of a Kaldor's fifth law.

This work is structured as it follows: besides this introduction, section two presents the laws proposed by Kaldor and contextualizes the services sector. After that, section three shows the procedure used to test the existence of Kaldor's fifth law. Section four presents this new law and consolidate the results obtained. Lastly, section five presents some final remarks.

\section{CONTRIBUTION OF THE INDUSTRIAL AND SERVICES SECTOR TO ECONOMIC GROWTH}

\subsection{KALDOR'S LAWS}

Kaldor $(1966,1970,1976)$ put forward three laws that try to explain the way in which economic growth occurs. The first law argues for the existence of a strong causal relation between industrial production growth and Gross Domestic Product (GDP) growth. That is, GDP growth is accelerated as the industry increases its participation in it, in detriment of the participation of other sectors. In order to arrive at that conclusion, Kaldor (1966, p. 8) estimated a regression for 12 industrialized countries, for the period between 1954 and 1964. The analyses conducted on these countries showed that the highest GDP growth rates are associated with the highest industrial production growth rates, compared to the economic production growth as a whole. 
Having identified that relationship, Kaldor (1966) asks why industrial production growth results in more economic growth when compared to other sectors. Kaldor's second law, also known as "Kaldor-Verdoorn law", proposes an answer to this question. It says that the industry added value growth causes an increase in productivity of this sector. From that regression, he shows that the industrial productivity increases as an answer to the increase in production of this sector.

Kaldor's third law shows that economic productivity growth is determined by industrial production and industrial employment. The existence of such relation is demonstrated through a regression estimation which has the product variation rate as independent variable and the product and industrial employment growth rate as dependent variable.

After verifying that increase in industrial production and industrial employment results in productivity growth in this sector, Kaldor (1966) proposes an explanation for this behavior. According to the author this explanation is found in Adam Smith, to whom the division of labor enables a higher level of specialization of the labor force. This in turn results in productivity growth. However, the level of the division of labor depends on the size of the market, the larger the market is, the higher is the differentiation, specialization and results obtained.

Adam Smith, Alfred Marshall and Allyn Young, cited by Kaldor (1966, p. 13), showed the manner in which dynamic and static factors contribute to increasing returns as an answer to a higher scale of operation in the industry. The more developed is the division of labor, the more skilled and knowledgeable are the workforce, and that results in productivity growth.

Besides that, as pointed out by Allyn Young in Kaldor's work (1966, p. 14), the presence of increasing returns is a macro-phenomenon. It is not the result of growth in any specific industry, but of the growth in industry as a whole. The growth of the industry should be seen as a dynamic process that generates microeconomic transformation. That is, changes in the way in which each company is conceived and interacts with one another in the market.

Industrial growth leads to the arrangement of the activities undertaken by the companies. In turn, through the division of labor, these companies are inserted in a growing process of productive specialization. As the demand for industrial goods grows, the companies become increasingly more specialized and that in turn results in higher productivity. Therefore, industrial production should be seen as a result emerging from the degree of productive specialization, and this one as being dependent on the level of development of the division of labor. The company representing the 
industry should be seen as something in constant change, considering that its conception and structure depend on the level development of the division of labor, which is determined by the size of the market. This, in turn, is determined by the size of the existing demand for industrial products.

On the other hand, Kaldor considers that the service sector growth is only a reflexion of the growth in other sectors of the economy. The increase in demand for services does not generate increase in productivity in this sector, as scale economies are non-existent in it. The lack of growth in productivity of the services sector, as the sector itself grows, and its inability to generate additional demand, makes it incapable of producing a selfstrengthening process of economic growth. That is, growth in the services sector is not capable of producing endogenous forces that in its turn are capable of starting a persistent process of economic growth, as it happens in the industrial sector.

Besides the three laws presented by Kaldor, Thirlwall (1979) introduced a fourth law, that had been proposed but not formalized by Kaldor. This law shows that the income elasticity of the national production explains the level of restriction on the balance of payment and the income growth capacity. Considering the fact that these relations have already been thoroughly discussed by Thirwall and the subsequent literature, we will not conduct a deep revision of literature on the subject.

\subsection{EMPIRICAL EVIDENCES ON THE CONTRIBUTION OF THE SERVICES TO ECONOMIC GROWTH}

Historically, the dynamic of economic growth was credited to the industry and to the agriculture sector. The services sector had been little studied, the literature did not recognize its contribution to economic growth (Oliveira, 2001). The first definition of the services sector were made by Fisher (1933) and Clark (1940) and they came with the need of characterizing a heterogeneous set of activities seen as residual.

In the 1970's and 1980's, the relative growth of the services sector in developed countries gained more visibility. In that period they began to discuss the consequences of the emergence of new technologies of communication on economic growth (Summer, 1985; Griliches, 1979, 1985).

According to OECD (2013), the development of new information and communication technologies contributed directly and indirectly to the growth of the services sector and to its increased influence over the industry. Directly, because the new technologies make use of various services and most 
part of the investment in this sector is placed on services. And, indirectly, because the development of new technologies facilitated communication, which reduced the need for physical proximity in the provision of services.

Easier communication contributed to various changes in the dynamic of the economy, among which stand out an increase of trade in services; growth of business services related to the management of global value chains; outsourcing and offshoring of services activities. All of these factors added to the the growth of the services sector; the advent of new activities; higher specialization and increased productivity. A considerable part of the increase in productivity has been transferred to the industry (Freund \& Weinhold, 2002; Hesse \& Rodrigue, 2006; Bryson, J. Daniels, P \& Warf, B. 2004; Miozzo \& Soete, 1999; Francois \& Woerz, 2008; Berlingieri, 2013; Cuandro-Roura \& Maroto-Sanches, 2011; Jorgenson \& Timmer, 2011).

Productivity outsourcing reduced the price of services. This reduction was passed to the transformation industry, resulting in increased productivity for this sector (Triplett \& Bosworth, 2004). Gains in productivity are higher to industries that make more use of business services and to industries that present higher growth rates for this services. Therefore, high-quality and productive services result in cheaper and better industrial products, which in turn result in higher competitiveness among the countries manufacturing these products (Berlingieri, 2013; Amiti \& Wei, 2005; Francois \& Woerz, 2008; Barker \& Forssell, 1992).

From the 1990's the services sector started being associate with the innovation capacity of countries (Miozzo \& Soete, 2001). According to this line of research, the services sector has been determining the capacity of countries to make technologically more complex products.

In particular, knowledge-intensive business services literature shows that the services sector influences the innovation capacity of the industry (Miles et al., 1995, Miles, 2008; Hertog, 2000; Muller, 2001; Czarnitzki, Rammer \& Spielkamp, 2000).

Given these evidences, which point to the relevance of the services sector, Arbache (2012) developed the cartesian representation known as space-industry. Chart 1 shows the dynamics of structural change proposed by Arbache (2012) is evidence to the contribution of the services sector to industrial competitiveness. The space-industry is made of four quadrants showing different structural changes through which a country needs to pass in order to ascend from poverty and achieve high levels of per capita income. It is constituted of three dimensions: i) industrial share in GDP; ii) 
industrial density, defined as the added value of the transformation industry divided by the country's population;iii) business services share in GDP.

Quadrant R2 is characterized by increasing demand for basic industrial products and by the development of a low added value industry and general services. These two factors evolve in parallel to the decrease in agriculture's share in GDP. In that stage urbanization and diversification of the productive structure take place. As demonstrated by Imbs and Wacziarg (2003), economies become more diversified to the extent that its income increases. These economies specialize only after achieving a high income level. Based on that, Rodrik (2004) concludes that what causes income growth is economic diversification and not its specialization. In addition to that, Rodrik (2012) shows that the industry has unconditional convergence in productivity. Rodrik (2014) also shows that it is the presence of unconditional convergence of industrial productivity that guarantees a country's migration to a medium income level.

Quadrant R1 represents the initial stage, in which the population is predominantly rural and agriculture is the strongest sector. This quadrant shows that the country has a productive structure specialized in primary activities (McMillan \& Rodrik, 2011), being stuck in the middle-income trap (Rodrik, 2004).

\section{(Chart 1) \\ THE PRODUCT SPACE}

The product Space

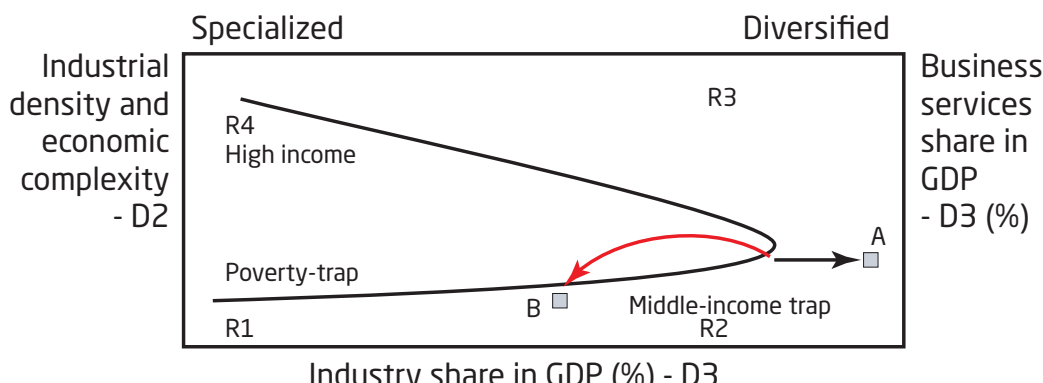

Source: Adapted from Arbache (2012).

Thus, the migration from from quadrant $\mathrm{R} 1$ to quadrant $\mathrm{R} 2$ represents the traditional structural change explained by Kaldor. He is able to demonstrate 
perfectly this migration stage. However, as discussed later in this paper, he is not able to explain the subsequent stages, marked by migration from quadrant R2 to quadrant R3 and from that to quadrant R4. As in these stages the growth capacity through unconditional convergence has already been exhausted, it is necessary to promote other measures in order to guarantee the migration from a medium income level to a high income level. Countries capable of moving forward in the process of structural change and expansion of its productive capacity migrate to quadrant R3. At this point, industrial activities demand for intermediate services is constantly increased and its share in GDP starts to drop (Arbache, 2014).

According to Rodrik (2014), industrialization is sufficient for the ascendance of a country from the poverty-trap to a the a medium income level. However, exclusive incentives to the industrial sector causes the country to fall in the middle-income trap (point A). Policies à la Kaldor steer a country away from its natural course of development, placing it outside the dynamic sectoral equilibrium, to an unstable position not sustainable in the long term. Development policies should instead create a more favorable environment for the diffusion and exchange of knowledge among the workforce and companies. They should stimulate the intermediate services sector, as only the development of this sector results in the migration of a country to the production of more complex products that generate higher income.

According to Rowthorn and Ramaswamy (1997, p. 6), the term deindustrialization is "used in the literature to refer to the secular decline in the share of manufacturing employment in advanced economies". It is important to point that to the authors this phenomenon should not be seen as something negative, or pathological, considering it as "an inevitable feature of the process of economic development". Therefore, the authors try to clarify that "deindustrialization is simply the natural outcome of the process of successful economic development, and is in general, associated with rising living standards". (Rowthorn \& Ramaswamy, 1997, p. 14). In other words, the migration from quadrant R2 to quadrant R3 is not harmful to a country.

Nevertheless, Rodrik (2016) shows that Latin American and Sub Saharan African countries have been going through a deindustrialization process (a return to point $B$ ). That is, they have been seeing a decrease in the degree of diversification of their productive structures, and a reduction of the participation of the industry and of the intermediate services in added value. The author shows that the loss of manufacturing employment is due, predominantly, among low skilled workers. The non-development of the 
required capabilities has been compromising the rise in income level for these countries.

Besides, the area $\mathrm{R} 4$ represents the most advanced stage of industrial development. In that quadrant the process of expansion of the industrial density continues and is followed by existence of a demand more than proportional for knowledge-intensive business services, whereas the share of the "traditional" industry declines (Arbache, 2014). That stage is also marked by the industry high demand for specific services and innovations in this sector, aiming at manufacturing products increasingly more sophisticated (HELPER et al. 2012, apud ARBACHE, 2014).

Quadrant R4 shows industrialized countries with high income levels. As demonstrated by Imbs and Wacziarg (2003), this quadrant is marked by the persistence in the decreasing trend in the industry's share in GDP and by an increase in specialization on products with high added value. It also shows a growing demand for advanced services, in such a way that these countries are distinguished for the manufacturing and offer of high-tech and high complexity services. According to Rodrik (2014) it is possible to argue that countries that migrate to $\mathrm{R} 4$ are the ones that were able to develop the capabilities required to the expansion of the intermediate services sector.

Chang (2012) argues that a higher share of the services sector does not diminishes the importance of the industry. According to the author the industry is the source of knowledge to the services sector. The acquisition of knowledge in the services sector occurs through the search for real solution to problems faced by the industrial sector. Knowledge in itself is not enough to guarantee competitiveness in the intermediate services sector. In other words, it is the interaction between industry and services that results in a higher industrial density and economic complexity.

As emphasized earlier, the increase in the share of the services sector results in the increase in economic complexity. This concept is presented by Hidalgo and Hausmann (2009). According to these authors, the way which society found to make sophisticated products is by breaking down into "pieces" the required knowledge for manufacturing them. These pieces of knowledge are acquired and shared among the workforce. Each worker learns and specializes in one part of the necessary knowledge, which is subsequently offered in the job market.

According to Hidalgo and Simões (2011), the productive capacity of each society can be measured by its capacity to retain, create, modify, organize, distribute and make use of the capabilities of its workforce. The most developed societies are the ones capable of managing more efficiently 
the knowledge they have. Strictly speaking, the amount of knowledge each individual has in a developed country is not different from the amount of knowledge an individual has in a developing country or in a poor country. It's not the individual retention of knowledge that distinguishes these countries. The key to the prosperity of some countries in detriment of others is found in their organizational capability to distribute knowledge among the workforce and to make collective use from increased amount of knowledge.

The empirical evidences indicate that countries with higher economic complexity are developed countries. Their services sector also present a higher share in added value. Therefore, the following question is raised, what is the relationship between the degree of development of the services sector and the level of complexity of the productive structure of a country? As showed by the services literature, this sector supply the industrial sector with the required knowledge. The rise in the amount of productive knowledge used by a country leads to the emergence of various services activities that exercise different functions and supply the industry with the necessary knowledge.

Stojkoski, Utkovski, Z. and Kocarev, L. (2016) show that countries that present higher services export have also higher a economic complexity index (ECI). This fact points that services require a larger amount of knowledge to be produced, comparing to other products. Besides, the results obtained show that economies whose export schedules is based on services have also more complex productive structures and higher long-term growth potential.

\section{METHODS AND PROCEDURES USED}

\subsection{METHODOLOGY USED}

The model proposed by Holtz-Eakin (1998) is used to estimate vector autoregression in panel data

$$
\Delta y_{i t}=\sum_{l=1}^{m} \alpha_{l t} \Delta y_{i t-1}+\sum_{l=1}^{m} \delta_{l t} \Delta x_{i t-1}+\Delta \mu_{i t}
$$

where $i$ is the country; $t$ is the period; $m$ is the number of countries; $y_{i t}$ is the independent variable; $x_{i t-l}$ is the independent variables vector; $\alpha_{i t}$ e $\delta_{i t}$ are the parameters associated to the dependent and independent variables and $\mu_{i t}$ is the error term. 
The estimation of (1) by OLS results in inconsistent estimators, as the residual $\Delta \mu_{i t}$ is correlated to the lags of the independent variable. Additionally, it is possible that the explanatory series are endogenous. Arellano and Bover (1995) and Blundell and Bover (1998) used delayed levels as instruments in difference regression and first difference as instruments in level regression. The estimator obtained is consistent and efficient, and were used to arrive at the results in equation (1).

The test proposed by Im et al. (2003) is used to verify if the series are stationary. The null hypothesis in this test is that all the series follow a stochastic process with unitary root:

HO: $\rho_{i}=0, \forall i \in \mathrm{N}$.

The alternative hypothesis is that only some series have unitary root:

$$
\mathrm{H} 1:\left\{\begin{array}{l}
\rho i<0 \text { para } i=1,2, \ldots, \mathrm{N}_{1} \\
\rho i=0 \text { para } i=\mathrm{N}_{1}+1, \ldots, \mathrm{N}
\end{array} .\right.
$$

The test is based on the arithmetic mean of the individual tests for unitary root:

$$
\bar{t}=\frac{1}{\mathrm{~N}} \sum_{i=1}^{N} t_{\rho i}
$$

so that $\bar{t} \sim N(0,1)$.

Moreover, Granger test of causality is used to identify the presence of causality between the series. The error correction mechanism points to the existence of causality in the long term. In order to do that, it is enough to test whether the estimated coefficient of the lagged error-correction term is significant. If the value found for the test $t$ is superior to the value of the statistic $t$ it is significant and, therefore, the hypothesis of the presence of causality between the series in the long term is not rejected:

$$
\begin{aligned}
& \Delta y_{i 1 t}=\alpha_{i t}+\beta_{i t} \mathrm{ect}_{i 2 t-1}+\sum_{i=1}^{1} \alpha_{1 i} \Delta \log \left(y_{i j-1}\right)+\sum_{i=1}^{1} \delta_{1 i} \Delta \log \left(x_{i t-1}\right)+\mu_{i t}, \\
& \Delta x_{i 1 t}=\alpha_{i t}+\beta_{i t} \mathrm{ect}_{i 1 t-1}+\sum_{i=1}^{1} \alpha_{i t} \Delta \log \left(y_{1 i t-1}\right)+ \\
& +\sum_{i=1}^{1} \delta_{i t} \Delta \log \left(x_{2 i t-1}\right)+\mu_{i t},
\end{aligned}
$$




$$
\Delta x_{i 2 t}=\alpha_{i t}+\beta_{i t} \text { ect }_{i 1 t-1}+\sum_{i=1}^{1} \alpha_{i t} \Delta \log \left(y_{i t-1}\right)+\sum_{i=1}^{1} \delta_{1 i} \Delta \log \left(x_{1 i t-1}\right)+\mu_{i t},
$$

where $\alpha_{i t}, \xi_{i t}, \beta_{i t}$ are parameters; $\Delta$ is the first difference operator; ect ${ }_{i t}$ is the error-correction term and $\mu_{i t}$ is white noise. When $\beta_{i t}$ are statically significant there are evidences of cointegration in the series and the presence of causality in the long term.

Granger causality test is done through the application of a Wald test. Therefore, in (4) the hypothesis that $x_{i t}$ causes $y_{i t}$ is tested based on the hypothesis: H01: $\delta_{11}=\delta_{12}=\ldots=\delta_{1 l}=0$; H02: $\alpha_{21}=\alpha_{22}=\ldots=\alpha_{21}=0$. If $\mathrm{HO} 1$ is rejected and $\mathrm{HO} 2$ is not rejected there are evidences that $y_{i t}$ causes $x_{i t}$. Similarly, if $\mathrm{HO1}$ is not rejected and $\mathrm{H02}$ is rejected there are evidences that $y_{i t}$ causes $x_{i t}$. Moreover, if $\mathrm{H} 01$ and $\mathrm{H} 02$ are rejected there are evidences of bidirectional causality between the series. Lastly, if $\mathrm{HO}$ and $\mathrm{HO2}$ are not rejected there are not causality between the series.

\subsection{TEST PROCEDURES}

The contribution of the size of the intermediate services sector to the increase in industrial productivity is tested by the following panel VAR model:

$$
\left.e_{m, t}=\alpha_{0}+\sum_{l=1}^{p} \alpha_{l} g_{m s, t-1}+\sum_{l=1}^{p} \beta_{l} g_{s, t-1}+\sum_{l=1}^{l} \gamma_{l} g_{k, t-1}\right),
$$

where, $e_{m t}$ is the industry employment growth rate, used as proxy to the industrial productivity; $g_{s t}$ value added growth rate of the services sector; $g_{k t}$ are control variables and $\alpha_{0} ; \alpha_{l} ; \beta_{l}$ and $\gamma_{l}$ parametric constants.

Industrial density, $D_{t}$, is a proxy used to test whether the development of the services sector enables the manufacturing of industrial products of higher technological content, as follows:

$$
D_{i, t}=\omega_{0}+\sum_{l=1}^{p} \omega_{l} D_{i, t-1}+\sum_{l=1}^{p} \Upsilon_{l} g_{s i, t-1},
$$

where $\omega_{0} ; \omega_{l}$ and $\Upsilon_{l}$ are parametric constants.

The hypothesis that the increase in industrial density results in higher growth for the services sector is also tested, that is:

$$
g_{s i, t}=\vartheta_{0}+\sum_{l=1}^{p} \vartheta_{l} g_{s i, t-1}+\sum_{l=1}^{p} \theta_{l} D_{i, t},
$$

being $\vartheta_{0}$ and $\vartheta_{l}$ and $\theta_{l}$ parametric constants. 
And the hypothesis that the Economic Complexity Index is related to the size of the services sector:

$$
C_{i, t}=\varphi_{0}+\sum_{l=1}^{p} \rho_{l} C_{i, t-1}+\sum_{l=1}^{p} \pi_{l} g_{s i, t-1},
$$

where $C_{i t}$ é o ICE; $g_{s i, t}$ is the services sector growth rate; and $\varphi_{0}, \rho_{l}$ and $\pi_{l}$ are parametric constants.

\subsection{DATA USED}

The data used to estimate the panel VAR model for the period 19852009 were obtained from Groningen Growth and Development Centre (GGDC). The only exception is capital stock, obtained from Pen World Table, and ECI, from the Observatory of Economic Complexity.

A problem faced when using this database is the definition given to services. Only two out of the five service sectors described by the GGDC were classified as intermediate services (transport, storage and communications; and finance, real estate and business services).

\section{RESULT ANALYSIS AND DISCUSSION}

\subsection{KALDOR'S FIFTH LAW}

Having presented the methodology that will be used, we have now the necessary arguments to question the existence of Kaldor's fifth law. This law argues that the intermediary service sector contributes to an increase in industrial competitiveness and defends the hypothesis that the emergence of a growing symbiotic relationship between these sectors contributes to an increase in production complexity.

Theorem: Service sector growth contributes to increase in industrial productivity, industrial density and economic complexity.

Corolário: This theorem adjusts the new evidences found by the service literature with the laws proposed by Kaldor.

The growth of industrial production contributes to productivity growth in this sector and to economic growth. However, this sector has a symbiotic relationship with the intermediary service sector. Based on Hidalgo and 
Hausmann (2009), Hidalgo and Simão. (2011), Foster-McGregor and Verspagen (2016), it is argued that the industry is characterized by the manufacturing of heterogeneous products, considering that increase in productivity and size of this sector the result of diversification of the range of products manufactured. Such diversification happens towards more complex products, which require an increasing large amount of knowledge to be produced. This knowledge in turn is supplied by the service sector. Thus, the growth of the intermediary services results in increased provision of knowledge, contributing to the diversification and growth of the industrial sector.

Kaldor affirms that the growth in industrial demand results in increased division of labor, increased production specialization and increased industrial production. The theorem above presented defends that the growth in industrial productivity does not rely only on increased industrial demand. The analysis conducted opens this sector and studies the characteristics of the its products, showing that the increase in industrial productivity happens through the diversification of the production and the migration to more sophisticated goods (Hidalgo \& Hausmann, 2009).

In order to understand the way in which the increase in industrial productivity contributes to the economic growth, it is necessary to go down to the level of the firms and understand how they behave. Firms aim at differentiate their production to benefit from higher profits. This in turn requires the manufacturing of more customized and sophisticated products. However, in order to do that, they need to make use of increasingly large amount of knowledge provided by firms in the service sector. Therefore, one of the main restrictions faced by firms is the need of coordination of the activities related to the external acquisition of increased volumes of knowledge.

New communication technologies facilitate the acquisition of that knowledge, allowing for the service sector to benefit from scale gains. As a consequence, the industry, strongly defended by Kaldor as the most dynamic sector of the economy, is no longer on its own. The emergence of new communication technologies brought with it the development of an increasing symbiotic relationship with the service sector. Thereby, economic growth came to be explained through the emergence of an increasing interaction between these sectors.

The proposition of this law enables the reconciliation of Kaldor's laws with the recent empirical evidences. It shows that the growth of the industry is still responsible for economic development. However, the growth of the service sector to the growth of its competitiveness. 


\subsection{RESULTS FOUND FOR THE REGRESSIONS}

Table 1 shows the results found for the unitary root test. As it is possible to observe, Im, Pesaram and Shin's test (2003) indicates that all the series are stationary in first difference.

\begin{tabular}{lccccc}
\hline \multicolumn{7}{c}{ (Table 1) } \\
\multicolumn{7}{c}{ RESULTS FOUND FOR THE UNITARY RO0T TEST } \\
\hline Série & Estatística & pvalor & Série & Estatística & pvalor \\
\hline$g_{m, i t}$ & $-0,48282$ & 0,3146 & $G_{s, i t}$ & 1,08911 & 0,8619 \\
\hline$d\left(g_{m, i t}\right)$ & $-376,082$ & 0,0001 & $d\left(g_{s, i t}\right)$ & $-1,1998$ & 0,1151 \\
\hline$g_{i t}$ & $-0,77167$ & 0,2202 & $D_{i t}$ & $-0,66549$ & 0,2529 \\
\hline$d\left(g_{i t}\right)$ & $-107,952$ & 0,1402 & $d\left(D_{i t}\right)$ & $-2,34399$ & 0,0095 \\
\hline$g_{k, i t}$ & 0,3658 & 0,6427 & $C_{i t}$ & 1,8571 & 0,9684 \\
\hline$d\left(g_{k, i t}\right)$ & $-182,718$ & 0,0338 & $D\left(C_{i t}\right)$ & $-6,2923$ & 0,001 \\
\hline
\end{tabular}

Source: Elaborated by the authors. ${ }^{\star} \mathrm{d}$ is the serie differentiated once. ${ }^{\#}$ value below 0,05 indicates that the serie is stationary.

As pointed out in section 4, a panel VAR model is chosen, which identifies whether the industry employment growth rate, used as proxy for industrial productivity, is explained by the industry and service's value added growth. Schwarz and Hanna-Quin's information criteria indicates that the panel VAR model must be estimated with a lag.

The value found for the estimated coefficients corroborate the hypothesis that the service sector's value added growth $\left(g_{s, i t}\right)$ causes Granger to increase industrial productivity $\left(e_{m, i t}\right)$, Table 2 . More specifically, the $1 \%$ variation in the service sector's value added results in $0,090 \%$ variation in the industry's productivity. Furthermore, the $1 \%$ variation in industrial production $\left(g_{m, i t}\right)$ results in $0,294 \%$ variation in productivity of this sector $\left(e_{m, i t}\right)$ and the $1 \%$ variation in its lagged productivity results in $0,424 \%$ variation in that same series.

The industrial density can be used as proxy to identify whether there is a relationship between the variation in the value added of the service sector and the variation in the industrial production technological content. Table 3 shows that the estimated parameters for both regressions are significant, indicating that the increase in industrial density, $D_{\text {ind }}$, causes Granger to 
increase the value added of the service sector, $g_{s}$. The variation in value added of the service sector also causes Granger variation in industrial density.

\section{(Table 2)}

VALUE FOUND FOR THE PANEL VAR MODEL WITH THE INDUSTRIAL PRODUCTIVITY AS DEPENDENT VARIABLE.

\begin{tabular}{lccccc}
\hline Variável & Coeficiente & Erro padrão & Variável & Coeficiente & Erro padrão \\
\hline$D\left(e_{m, i t-1}\right)$ & $0,424^{*}$ & $-0,079$ & $D\left(g_{k, i t-1}\right)$ & $-0,035$ & $-0,165$ \\
\hline$D\left(g_{m, i t-1}\right)$ & $0,294^{*}$ & $-0,052$ & $C$ & $-0,016^{*}$ & $-0,005$ \\
\hline$D\left(g_{s, i t-1}\right)$ & $0,090^{*}$ & $-0,049$ & & & \\
\hline$R^{2}$ & 0,410 & $-0,165$ & $F$ & 38,127 & \\
\hline $\begin{array}{l}\text { Autocorrelation - } \\
\text { Portmanteau }\end{array}$ & 49,815 & & pvalor & 0 & \\
\hline $\begin{array}{l}\text { Breusch Pagan - } \\
\text { Heterocedasticity }\end{array}$ & 239,654 & & pvalor & 0 & \\
\hline
\end{tabular}

Source: Elaborated by the authors.

\section{(Table 3)}

RESULTS FOUND FOR THE PANEL VAR MODEL FOR INDUSTRIAL DENSITY AGAINST THE VALUE ADDED OF THE SERVICE SECTOR

\begin{tabular}{lccccc}
\hline & \multicolumn{3}{c}{$g_{s}$} & $D_{\text {int }}$ & \\
\hline Variável & Coeficiente & Erro padrão & Variável & Coeficiente & Erro padrão \\
\hline$D\left(g_{\text {s,it-1 }}\right)$ & $0,606^{*}$ & 0,084 & $D\left(g_{\text {ind,it-1 }}\right)$ & $1,318^{*}$ & 0,07822 \\
\hline$D\left(D_{\text {ind,it-1 }}\right)$ & $20587,532^{*}$ & 4608,7 & $D\left(g_{s, i t-1}\right)$ & $-6,30 E-06^{*}$ & $1,40 E-06$ \\
\hline$C$ & $-14175,350$ & 437592 & $C$ & 1,354 & $-7,42703$ \\
\hline$R^{2}$ & 0,950 & & $R^{2}$ & 0,957 & \\
\hline$F$ & 2201,427 & & $F$ & 2580,795 & \\
\hline Autocorrelation - & 18,594 & pvalor & 0,0009 & & \\
Portmanteau & & & & & \\
\hline $\begin{array}{l}\text { Breusch Pagan - } \\
\text { Heterocedasticity }\end{array}$ & 98,713 & pvalor & 0,00 & & \\
\hline
\end{tabular}

Source: Elaborated by the authors. * significance at 95\% confidence level. 
These results corroborate the evidences obtained by Arbache (2014) and indicate that the causal relation is bidirectional. Industrial development contributes to the emergence of service activities. However, the emergence of service activities also contributes to the increase in industrial density.

A Table 4 shows the estimated results for the panel VAR model for the ECI regression against the value added of the service sector. The estimated coefficients indicate that the variation in the value added of the service sector causes Granger variation in the ECI. Furthermore, the variation in ICA also causes Granger variation in the value added of the service sector.

\section{(Table 4)}

RESULTS FOUND FOR THE ECI REGRESSION AGAINST
THE VALUE ADDED OF THE SERVICE SECTOR.

\begin{tabular}{lcccc}
\hline & \multicolumn{1}{c}{$C_{i t}$} & $g_{s i}$ & \\
\hline Variável & $\begin{array}{c}\text { Coeficientes } \\
\text { estimados }\end{array}$ & Desvio Padrão & Coeficientes estimados & Desvio Padrão \\
\hline$C_{i t-1}$ & $-0,0241$ & 0,000 & $4,60 \mathrm{E}+7^{*}$ & $-2,22 \mathrm{E}+7$ \\
\hline$C_{i t-2}$ & 0,027 & 0,000 & $5,951 \mathrm{E}+7^{*}$ & $-2,22 \mathrm{E}+7$ \\
\hline$g_{s i, t-1}$ & $9,49 \mathrm{E}-9^{*}$ & 0,000 & $1,202^{*}$ & $-0,081$ \\
\hline$g_{s, i t-1}$ & $-9,02^{*}$ & 0,000 & $-0,463^{*}$ & $-0,083$ \\
\hline$C$ & $-8,15 \mathrm{E}-3$ & 0,000 & $1,25 \mathrm{E}+5$ & $-2,06 \mathrm{E}+6$ \\
\hline$R^{2}$ & 0,078 & & 0,585 & \\
\hline$F$ & 4,456 & & 74,537 & \\
\hline
\end{tabular}

Source: Elaborated by the authors, * significance at 95\% confidence level.

These results corroborate the evidences raised by Stojkoski at al. (2016). The increase in the size of the service sector explains the ECI growth. That could indicate that the level of development of the service sector influences the degree of complexity of a country's production structure. Therefore, the emergence of support service activities enables the manufacturing of products that demand increased amount of knowledge. However, the causal relation is bidirectional, the increase in economic complexity also demands the growth of the service sector. 
The results found for the estimated models do not reject the proposed theorem. The estimations performed identified the presence of bidirectional causality between these sectors. Therefore, the hypothesis of the existence of a Kaldor's fifth law is not rejected. The production of more sophisticated industrial goods contributes to the growth of the intermediate service sector which in turn contributes to growth in industrial productivity and to the manufacturing of products with increased technology-intensity.

\section{FINAL REMARKS}

Kaldor proposed four laws defining the industry as being responsible for economic development. According to Kaldor (1966), in order to develop, countries must adopt policies that stimulate growth and increase participation of the industry in value added.

Parallel to that, the services literature shows that the contribution of this sector to economic development has increased since the 1980's, with the advent of new communication technologies. In particular, KIBS literature shows that part of the innovation, observed from the 1980's, came from the service sector.

In its turn, the economic complexity literature defends that economic development is explained by the expansion of the production knowledge base possessed by a country. Arbache (2012) finds a positive relationship between industrial density and the participation of the service sector and Rodrik (2014) arguments that the adoption of incentive and training development policies for the intermediary service sector has the power to take countries out of the middle income-trap. Moreover, according to Stojkoski et al. (2016), the manufacturing of more complex products is associated with the development of the service sector.

In view of these evidences, this paper questions whether there is a fifth Kaldor's law. If so, it affirms that the growth of the industrial productivity is explained by the growth of this sector, as defended by Kaldor, but also due to the growth of the service sector. In order to test this hypothesis, panel VAR models are estimated, verifying whether the growth of industrial productivity, industrial density and Economic Complexity Index are explained by the growth of value added in the service sector.

The results found for the estimated regressions corroborate the proposed hypothesis. Kaldor's laws are not wrong, but they need to be put into context. Kaldor analyzed the historical process of development before the occurrence 
of the natural deindustrialization phenomenon in advanced economies. This phenomenon represents a new period in economic development, in which services contribute to the increase in industrial competitiveness. With the emergence of innovation technologies, the existent relationship between industry and services began to change, and the presence of increasing symbiosis between these sectors contributed to the manufacturing of more technologically sophisticated products.

Furthermore, the results found also corroborate the argument made by Kon (2015). Economic development is caused by the expansion of the production knowledge base possessed by a country. The production of more sophisticated products means that an increased amount of knowledge is required. There is the need for various activities to support the industry, activities that are capable of providing it with the required knowledge. This support to the industry is given by the service sector and the development of this sector contributes to the manufacturing of products with high levels technological sophistication.

As stressed by Hidalgo and Hausmann (2009) and Hidalgo and Simões (2011), economic development must be seen as the capacity for organization increasingly more extensive and complex chain production. The service sector contributes to the production of more technologically sophisticated products. Thereby, the results obtained do not reject the proposed hypothesis. They represent initial evidences favorable to the existence of a Kaldor's fifth law. In order to achieve high income level per capita a country needs to jointly develop its intermediate service sector and its industry. The way in which these sectors interconnect and complement each other influences the capacity for economic growth of a nation.

Lastly, the limitations of this work are emphasized. The proposed law is still at an early stage and is in need of more robust tests proving its validity. Further studies should be conducted using larger samples, including more countries and for longer periods, verifying if the results found are still apply.

\section{REFERENCES}

Amiti, M., \& Wei, S. J. (2005). Fear of service outsourcing: is it justified? Economic policy, 20(42), 308-347. doi 10.3386/w10808.

Arbache, J. (2012). Is Brazilian Manufacturing Losing its Drive? doi 10.2139/ ssrn.2150684. 
Arbache, J., \& Aragão, C. (2014). Infraestrutura e competitividade da indústria brasileira. Retrieved from http://economiadeservicos.com/wp-content/ uploads/2015/06/infraestrutura-e-competitividade-industrial-19nov2014arbache-aragao.pdf.

Arbache, J. (2015). Produtividade no setor de serviços. In Negri, F. de, \& Cavalcante, L. R. (2015). Produtividade no Brasil desempenho e determinantes (Vol. 2, pp. 277-300). Brasília, DF: Instituto de Pesquisa Econômica Aplicada. Barker, T. \& Forssell, O. (1992). Manufacturing, Services and Structural Change, 1979-1984. In Driver, C.; Dunne editors. Structural change in the UK economy. Cambridge University Press. doi 10.1080/09535319000000013.

Baumol, W. J. (1967). Macroeconomics of unbalanced growth: the anatomy of urban crisis. The American economic review, 57(3), 415-426. doi $10.2307 / 1812111$.

Berlingieri, G. (2013). Essays on international trade and firm organization. Doctoral dissertation, London School of Economics (LSE), London, United Kingdom.

Bryson, J., Daniels, P., \& Warf, B. (2013). Service worlds: People, organisations, technologies. Abingdon, United Kingdom: Routledge.

Bronfembrenner, M. (1969). Strategic factors in economic development, Nicholas Kaldor. Economic Development and Cultural Change, 17(2), 277-280. doi $10.1086 / 450356$.

Chang, H. J. (2012). The manufacturing sector and the future of Malaysia's economic development. Jurnal Pengurusan, 35, 3-12.

Clark, C. (1940). The Conditions of Economic Progress. London, United Kingdom; MacMillan.

Cuadrado-Roura, J. R., \& Maroto-Sanchez, A. (2011). Regional productivity growth in European countries: the role of services. Paper presented at the 50th Anniversary European Congress of the Regional Science Association International (ERSA), Sweden. Retrieved from http://www-sre.wu.ac.at/ ersa/ersaconfs/ersa10/ERSA2010finalpaper163.pdf.

Czarnitzki, D., Rammer, C., \& Spielkamp, A. (2000). Interaktion zwischen Wissenschaft und Wirtschaft in Deutschland: Ergebnisse einer Umfrage bei Hochschulen und öffentlichen Forschungseinrichtungen. Mannheim, BadenWürttemberg: ZEW GmbH.

Fisher, I. (1933). Statistics in the Service of Economics. Journal of the American Statistical Association, 28(181), 1-13. doi 10.1080/01621459.1933.10502629. 
Foster-McGregor, N., \& Verspagen, B. (2016). The Role of Structural Transformation in the Potential of Asian Economic Growth. Asian Development Bank Economics Working Paper Series (479). Retrieved from https://www.adb. org/sites/default/files/publication/182277/ewp-479.pdf.

Francois, J., \& Woerz, J. (2008). Producer services, manufacturing linkages, and trade. Journal of Industry, Competition and Trade, 8(3), 199-229.

Freund, C., \& Weinhold, D. (2002). The Internet and international trade in services. The American Economic Review, 92(2), 236-240. doi $10.1257 / 000282802320189320$.

Griliches, Z. (1979). Issues in assessing the contribution of research and development to productivity growth. The bell journal of economics, 10(1), 92-116. doi 10.3386/w1547.

Griliches, Z. (1985). Productivity, R\&D, and basic research at the firm level in the 1970s. American Economic Review, 76(1), 141-154.

Hertog, P. D. (2000). Knowledge-intensive business services as co-producers of innovation. International Journal of Innovation Management, 4(4), 491-528. doi 10.1142/S136391960000024X.

Hesse, M., \& Rodrigue J. (2004). The Transport Geography of Logistics and Freight Distribution. Journal of Transport Geography, 12(3), 171-84. doi 10.1016/j.jtrangeo.2003.12.004.

Rodrigue, J. (2006). Transportation and the Geographical and Functional Integration of Global Production Networks. Growth and Change, 37(4), 51025. doi 10.1111/j.1468-2257.2006.00338.x.

Hidalgo, C. A., \& Simoes, A. J. G. (2011). The Economic Complexity Observatory: An analytical tool for understanding the dynamics of economic development. Workshops at the 25th AAI Conference on Artificial Intelligence, United States of America. Retrieved from https://www.aaai.org/ocs/index.php/ WS/AAAIW11/paper/view/3948/4325.

Hidalgo, C. A., \& Hausmann, R. (2009). The building blocks of economic complexity. Proceedings of the National Academy of Sciences of the United States of America, 106(26), 10570 - 10575. doi 10.1073/pnas.0900943106.

Holtz-Eakin, D., Newey, W., \& Rosen, H. (1988). Estimating vector autoregressions with panel data. Econometrica, 56(6), 1371-1395.

Imbs, J.; Wacziarg, R. (2003). Stages of diversification. The American Economic Review, 93(1), 63-86. doi 10.1257/000282803321455160. 
Jorgenson, D. W., \& Timmer, M. P. (2011). Structural Change in Advanced Nations: A New Set of Stylised Facts. The Scandinavian Journal of Economics, 113(1), 1-29. doi 10.1111/j.1467-9442.2010.01637.x.

Kaldor, N. (1966). Causes of the slow rate of economic growth of the United Kingdom: an inaugural lecture, 36(2), 222-222. doi 10.1017/S0770451800040616.

Kaldor, N. (1970). The case for regional policies. Scottish journal of political economy, 17(3), 337-348. doi 10.1111/j.1467-9485.1970.tb00712.x.

Kaldor, N. (1976). Inflation and recession in the world economy. The Economic Journal, 86(344), 703-714. doi 10.2307/2231447.

Kaldor, N. (1972). The irrelevance of equilibrium economics. The Economic Journal, 82(328), 1237-1255.

Katouzian, M. A. (1970). The development of the service sector: a new approach. Oxford Economic Papers, 22 (3), 362-382.

Kon, A. (2015). A Nova Economia Política dos Serviços. São Paulo: Editora Perspectiva.

McMillan, M. S., \& Rodrik, D. (2011). Globalization, structural change and productivity growth. NBER Working Paper (17143). doi 10.3386/w17143.

Miles, I., Kastrinos, N., Bilderbeek, R., Hertgo, P. den, Flanagan, K., Huntink, W., \& Bouman, M. (1995). Knowledge-intensive business services: users, carriers and sources of innovation. European Innovation Monitoring System Reports, Belgium.

Miles, I. (2008). Patterns of innovation in service industries. IBM Systems journal, 47(1), 115-128. doi 10.1147/sj.471.0115.

Miozzo, M., \& Soete, L. (2001). Internationalization of services: a technological perspective. Technological Forecasting and Social Change, 67(2), 159-185. doi 10.1016/S0040-1625(00)00091-3.

Muller, E., \& Zenker, A. (2001). Business services as actors of knowledge transformation: the role of KIBS in regional and national innovation systems. Research policy, 30(9), 1501-1516. doi 10.1016/S0048-7333(01)00164-0.

Oliveira, P., \& Hippel, E. von. (2011). Users as service innovators: the case of banking services. Research Policy, 40(6), 806-818.

Rodrik, D. (2004). Industrial policy for the twenty-first century. CEPR Discussion Paper, (4767). doi 10.1093/acprof:oso/9780198739890.003.0008

Rodrik, D. (2012). Unconditional convergence in manufacturing. The Quarterly Journal of Economics, 128(1), 165-204. doi 10.1093/qje/qjs047. 
Rodrik, D. (2014). The past, present, and future of economic growth. Challenge, 57(3), 5-39. doi 10.2753/0577-5132570301.

Rodrik, D. (2016). Premature deindustrialization. Journal of Economic Growth, 21 (1), 1-33. doi 10.3386/w20935.

Rowthorn, R. E., \& Ramaswamy, R. (1997). Deindustrialization: causes and implications. IMF Working Paper, (97/42). doi 10.3386/w20935.

Stojkoski, V., Utkovski, Z., \& Kocarev, L. (2016). The impact of services on economic complexity: service sophistication as route for economic growth. PLOS ONE 11(8). doi 10.1371/journal.pone.0161633.

Thirlwall, A. P. (1983). The balance of payments constraint as an explanation of international growth rate differences. Banca Nazionale del Lavoro Quarterly Review, 32(128), 45-53. doi 10.1057/9781137409485_15.

Triplett, J. E., \& Bosworth, B. P. (2006). Baumol's Disease'has been cured: IT and multifactor productivity in US services industries. In Jansen, D. W. (Ed.), The new economy and beyond: Past, present, and future (pp. 34-71). Massachusetts, United States of America: Edward Elgar Publishing Inc. 